\title{
Pliocene Model Intercomparison Project (PlioMIP): experimental design and boundary conditions (Experiment 2)
}

\author{
A. M. Haywood ${ }^{1}$, H. J. Dowsett ${ }^{2}$, M. M. Robinson ${ }^{2}$, D. K. Stoll ${ }^{2}$, A. M. Dolan ${ }^{2}$, D. J. Lunt ${ }^{3}$, B. Otto-Bliesner ${ }^{4}$, and \\ M. A. Chandler ${ }^{5,6}$ \\ ${ }^{1}$ School of Earth and Environment, University of Leeds, Woodhouse Lane, Leeds, LS2 9JT, UK \\ ${ }^{2}$ Eastern Geology and Paleoclimate Science Center, U.S. Geological Survey, MS926A, 12201 Sunrise Valley Drive, Reston, \\ VA 20192, USA \\ ${ }^{3}$ School of Geographical Sciences, University of Bristol, University Road, Bristol, BS8 1SS, UK \\ ${ }^{4}$ CCR, CGD/NCAR, P.O. Box 3000, Boulder, CO 80307-3000, USA \\ ${ }^{5}$ Center for Climate Systems Research, Columbia University, 2880 Broadway, New York, NY, 10025, USA \\ ${ }^{6}$ NASA Goddard Institute for Space Studies, New York, NY, USA
}

Received: 18 February 2011 - Published in Geosci. Model Dev. Discuss.: 2 March 2011

Revised: 27 June 2011 - Accepted: 1 July 2011 - Published: 1 July 2011

\begin{abstract}
The Palaeoclimate Modelling Intercomparison Project has expanded to include a model intercomparison for the mid-Pliocene warm period (3.29 to 2.97 million yr ago). This project is referred to as PlioMIP (the Pliocene Model Intercomparison Project). Two experiments have been agreed upon and together compose the initial phase of PlioMIP. The first (Experiment 1) is being performed with atmosphereonly climate models. The second (Experiment 2) utilises fully coupled ocean-atmosphere climate models. Following on from the publication of the experimental design and boundary conditions for Experiment 1 in Geoscientific Model Development, this paper provides the necessary description of differences and/or additions to the experimental design for Experiment 2.
\end{abstract}

\section{Introduction}

The mid-Pliocene warm period (mPWP) is defined by the United States Geological Survey's PRISM Group (Pliocene Research Interpretation and Synoptic Mapping; http:// geology.er.usgs.gov/eespteam/prism/index.html) as the interval between 3.29 and $2.97 \mathrm{Ma}$ (according to the geomagnetic polarity timescale of Berggren et al. 1995), lying between the transition of oxygen isotope stages M2/M1 and G19/G18 (Shackleton et al., 1995), in the middle part of the Gauss Normal Polarity Chron (Dowsett et al., 1999). The "Time Slab"

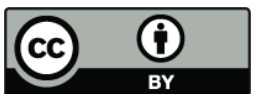

Correspondence to: A. M. Haywood (earamh@leeds.ac.uk) represents a climatically distinct period during the Pliocene when Earth's climate was, on the whole, warmer than present (Dowsett et al., 1999; Dowsett, 2007).

The mPWP has been the subject of intense study for the last two decades. There are many reasons for this, but an important driver has been our desire to understand the dynamics of past warm climates as a potential guide to understanding climate change in the future (Haywood et al., 2009). The mPWP is well suited to this task. The climatic signal (change from modern) is sufficiently large, for many geographical regions, to be differentiated from the noise generated by the uncertainties and limitations inherent in the techniques used for palaeoclimatic/palaeoenvironmental reconstruction. The interval was the last time in Earth history when global temperatures were significantly warmer than modern, over a period longer than any Quaternary interglacial. It is unique in that continental configurations were relatively unchanged from today, and geological proxies are superior to those of preceding warm periods due to improved geographic coverage, more reliable biota-environment correlations and higher resolution stratigraphy (Dowsett, 2007).

For the initial phase of the Pliocene Model Intercomparison Project (hereafter referred to as PlioMIP), which is a subcomponent of the wider/larger Palaeoclimate Modelling Intercomparison Project (PMIP; Braconnot et al., 2007a,b) two experiments were agreed upon. The first is an experiment using atmosphere-only climate models (hereafter referred to as Experiment 1), the details of which can be found in Haywood et al. (2010; this journal and issue), whilst the second experiment (hereafter referred to as Experiment 2) will utilise coupled ocean-atmosphere climate models. Both experiments

Published by Copernicus Publications on behalf of the European Geosciences Union. 
use versions of the US Geological Survey's PRISM Group boundary condition data sets (e.g. Dowsett, 2007). This Special Issue of Geoscientific Model Development represents the first set of co-ordinated publications from PlioMIP. It (a) describes the chosen experimental design for Experiments 1 and 2, (b) includes a detailed description of the boundary conditions used in both experiments, and (c) presents contributions from each participating model group, describing how the boundary conditions were implemented into the different climate models and the basic results from the experiments themselves. This detailed record for the rationale and specifics of the experimental design, construction of the boundary conditions data sets, and critically, how these were implemented into each climate model, will provide an invaluable reference when the intercomparison phase of PlioMIP is reached. This will help the PlioMIP/PMIP community to understand more easily the differences which will inevitably be observed between mid-Pliocene warm period (mPWP) simulations. The purpose of this paper is to briefly describe the experimental design and boundary conditions for PlioMIP Experiment 2, focussing only on the aspects that differ from Experiment 1. Participating groups should refer to Haywood et al. (2010), for full details of Experiment 1 and for details relevant to Experiment 2 that are not repeated here.

\section{Experimental Design - Experiment 2}

\subsection{Integration, atmospheric gases/aerosols, solar constant/orbital configuration}

The experimental design for Experiment 2 is summarised in Table 1. The experiment integration length was set to $500 \mathrm{yr}$ in accordance with CMIP5 guidelines (Coupled Model Intercomparison Project Phase 5) for coupled model experiments (see: http://cmip-pcmdi.llnl.gov/cmip5/docs/Taylor_CMIP5_ design.pdf).

As in PlioMIP Experiment 1, the concentration of $\mathrm{CO}_{2}$ in the atmosphere was set to $405 \mathrm{ppmv}$. In the absence of any adequate proxy data, all other trace gases and aerosols were specified to be consistent with the individual group's pre-industrial control experiments.

When trying to specify $\mathrm{CO}_{2}$ as far back in time as the Pliocene epoch uncertainty is inevitable. Evidence for Pliocene $\mathrm{CO}_{2}$ comes from a number of sources: (1) the stomatal density of fossil leaves (Kürschner et al., 1996), (2) carbon isotope analyses (e.g. Raymo et al., 1996), (3) alkenonebased estimates (Pagani et al., 2010; Seki et al., 2010) and (4) boron isotope analyses (e.g. Seki et al., 2010). The values of $\mathrm{CO}_{2}$ from each of these proxies differ. However, within error they overlap. The stomatal density records support a $\mathrm{CO}_{2}$ of 350 to 380 ppmv. The average of the Raymo carbon isotope analyses is similar to the stomatal-based estimates but peaks above that value (beyond $425 \mathrm{ppmv}$ ) occur and are entirely plausible. The Pagani et al. study looked at reconstructed
$\mathrm{CO}_{2}$ from a number of different marine records and the work shows clearly that in three of the six marine records a $\mathrm{CO}_{2}$ value of 400 or 405 is perfectly reasonable and the $\mathrm{CO}_{2}$ range stated by Pagani et al. (2010) is 365 to 415 ppmv. In the Seki et al. (2010) study the alkenone-based $\mathrm{CO}_{2}$ record is consistent with a value around 400 ppmv. The highest resolution section of the Seki et al. (2010) boron isotope record shows a decline in $\mathrm{CO}_{2}$ from 400 to 280 after 3 million yr. Pliocene $\mathrm{CO}_{2}$ is an important ongoing area of research with new records coming online in the next few years. Beyond Experiment $2, \mathrm{CO}_{2}$ is an obvious choice for sensitivity tests as part of PlioMIP and is one of the many justifications for utilising coupled ocean-atmosphere models within the project.

The solar constant and orbital configuration was specified as the same as each participating group's pre-industrial control run. The PRISM data set of mid-Pliocene boundary conditions (Dowsett, 2007) represents an average of the warm intervals during the time slab (3.29 to 2.97 million yr) rather than a discrete time slice, making it challenging to prescribe an orbital configuration which is representative of the entire $\sim 300000 \mathrm{yr}$ interval. Furthermore, it is difficult to provide an average insolation forcing at the top of the atmosphere in some climate models, with some models requiring specific values for eccentricity, obliquity and precession. Therefore, PlioMIP decided to specify a modern orbital configuration, even though available astronomical solutions (e.g. Laskar et al., 2004) indicate that this may not provide the most representative mean orbital forcing for the mPWP (see Haywood et al., 2010). In the future this uncertainty can be explored through sensitivity experiments in which the orbital configuration is changed and provides a further justification of the implementation of coupled-ocean atmosphere models in PlioMIP.

\subsection{Adoption/availability of a "Preferred" and "Alternate" experimental design}

Two boundary condition data packages are available - "preferred" and "alternate". Versions 1.0 of both data packages are provided on the PlioMIP website (http://geology.er. usgs.gov/eespteam/prism/prism_pliomip_data.html), and are provided as supplementary information to this paper. The preferred data package requires the ability to change the model's land/sea mask to a mid-Pliocene configuration. The alternate data package, with a modern land/sea configuration, is provided in order to maximise the potential number of participating groups in PlioMIP, since it is difficult in some climate models to successfully alter the land/sea mask. Groups that are not able to change their land/sea mask were asked to use their own modern land/sea mask. However, a PRISM3D/PlioMIP modern land/sea mask is provided in the alternate package to help guide the implementation of midPliocene topography and vegetation etc. into different climate models. 
Table 1. Experimental design - PlioMIP Experiment 2.

\begin{tabular}{|c|c|c|c|}
\hline \multicolumn{4}{|l|}{$\begin{array}{l}\text { Model Coupling } \\
\text { Atmosphere-Ocean }\end{array}$} \\
\hline \multicolumn{4}{|c|}{ Integration Length } \\
\hline \multicolumn{4}{|l|}{ Oceans } \\
\hline \multicolumn{2}{|l|}{ Ocean Mode } & \multicolumn{2}{|l|}{ Deep Ocean Input } \\
\hline \multicolumn{2}{|c|}{$\begin{array}{l}\text { Dynamic - initialized with PRISM3 ocean } \\
\text { temperatures if possible or Pre-Ind Control }\end{array}$} & \multicolumn{2}{|c|}{$\begin{array}{l}\text { Global_dot_v2.0* if possible or } \\
\text { same as Pre-Ind Control }\end{array}$} \\
\hline \multicolumn{4}{|c|}{ Preferred Boundary Conditions } \\
\hline Land/Sea Mask & Topography & Ice Sheets & Vegetation \\
\hline $\begin{array}{l}\text { PRISM3D } \\
\text { (land_fraction_v1.1) }\end{array}$ & $\begin{array}{l}\text { PRISM3D } \\
(\text { topo_v1.1*) }\end{array}$ & $\begin{array}{l}\text { PRISM3D } \\
\text { (biome_veg_v1.3 or } \\
\text { mbiome_veg_v1.3) }\end{array}$ & $\begin{array}{l}\text { PRISM3D or } \\
\text { (biome_veg_v1.3 or } \\
\text { mbiome_veg_v1.3) }\end{array}$ \\
\hline \multicolumn{4}{|c|}{ Alternate Boundary Conditions } \\
\hline Land/Sea Mask & Topography & Ice Sheets & Vegetation \\
\hline $\begin{array}{l}\text { Local modern land/ } \\
\text { sea mask }\end{array}$ & $\begin{array}{l}\text { PRISM3D } \\
(\text { topo_v1.4*) }\end{array}$ & $\begin{array}{l}\text { PRISM3D } \\
\text { (biome_veg_v1.2 or } \\
\text { mbiome_veg_v1.2) }\end{array}$ & $\begin{array}{l}\text { PRISM3D } \\
\text { (biome_veg_v1.2 or } \\
\text { mbiome_veg_v1.2) }\end{array}$ \\
\hline \multicolumn{4}{|l|}{ Greenhouse Gases } \\
\hline $\mathrm{CO}_{2}$ & $\mathrm{CH}_{4}$ & CFCs & $\mathrm{O}_{3}$ \\
\hline 405 ppm As Pre-Ind & Control As Pre-Ind Control & As Pre-Ind Control & As Pre-Ind Control \\
\hline \multicolumn{4}{|l|}{$\begin{array}{l}\text { Solar Constant } \\
\text { As Pre-Ind Control }\end{array}$} \\
\hline \multicolumn{4}{|l|}{ Aerosols } \\
\hline \multicolumn{4}{|l|}{ Model Spin-up } \\
\hline
\end{tabular}

* Applied as an anomaly to control experiment data sets used by each participating group rather than as an absolute.

Those groups who are able to adopt the preferred experimental design will have to adjust the bathymetry of the deglaciated West Antarctic region. To avoid numerical instabilities groups will specify a flat bathymetry with an average depth of $500 \mathrm{~m}$. This bathymetry will be graded into the modern bathymetry. For those models which are very sensitive to bathymetric alteration, groups are free to do what is necessary to enable a simulation to be successfully completed.

Given the absence of a global data set for mPWP bathymetry in all other regions ocean bathymetry will be specified as modern. However, there has been a discussion recently regarding the depth of potentially critical sills in the North Atlantic (e.g. Jones et al., 2002). Robinson et al. (2011) have shown that the exact depth of the Greenland-
Scotland Ridge specified in coupled climate models can have a significant effect on model predictions of North Atlantic Deepwater formation (NADW), thermohaline circulation (THC) and increased SSTs in the North Atlantic and Arctic. Investigation of such uncertainties is beyond the scope of the first phase of PlioMIP but could become a focus for sensitivity tests in the future.

\subsection{Implementation of ocean temperatures and topography as an anomaly}

To ensure that the climate anomalies (mid-Pliocene minus present day) from all PlioMIP climate models are directly comparable, i.e. that they reflect differences in the models themselves rather than the differences of modern boundary 
conditions, it was decided to implement both the Pliocene topography and initial sea surface temperatures (SST) (from Experiment 1) and SST and deep ocean temperatures (from Experiment 2) as an anomaly to the standard modern ocean temperature and topographic data set used by each modelling group's individual model. For Experiment 2 to create the initial Pliocene ocean temperature and topography, the difference between the PRISM Pliocene and PRISM Modern ocean temperatures and topography will be calculated and added to the modern ocean temperature and topographic data sets each participating modelling group employs.

In other words:

$$
\begin{aligned}
\text { Topo_Plio } & =(\text { Topo_Plio_PRISM3D } \\
& - \text { Topo_Modern_PRISM3D }) \\
& + \text { Topo_Modern_Local }
\end{aligned}
$$

and

$$
\begin{aligned}
\text { OceanT_Plio } & =(\text { OceanT_Plio_PRISM3D } \\
& - \text { OceanT_Modern_PRISM3D }) \\
& + \text { OceanT_Modern_Local }
\end{aligned}
$$

However, when using such a method, a potential mismatch between mid-Pliocene and modern topography landsea masks is possible. This will be overcome by using absolute Pliocene topography and ocean temperatures in regions where no modern data are given (such as for the Pliocene topography in the Hudson Bay region). Modern SSTs are projected on the same Pliocene grids (preferred and alternate) to make anomalies easier to generate. There may be mismatches (for example in the West Antarctic region) between the Pliocene deep ocean temperature data, where it is provided, and the Pliocene land/sea mask. Where this is the case, Global_dot_v2.0 deep ocean temperatures should be extrapolated horizontally into regions with no data coverage, therefore maintaining the Global_dot_v2.0 vertical temperature profile. Groups unable to alter the initial ocean temperature state should begin the simulation with a modern control state and document the spin-up of the simulation. Salinity should be derived from Levitus and Boyer (1994) or an existing modern (control) simulation. The starting atmospheric conditions for Experiment 2 should be derived from the end of Experiment 1 if possible.

\section{Description of Boundary Conditions (PRISM3D)}

A full description of the mPWP land-sea mask (including the nature of ocean gateways) and topography (outside of ice sheet regions), ice sheet height and extent, SST (see Fig. 1), sea-ice extent, vegetation type and distribution, soils, lakes and river routing is provided in Haywood et al. (2010; this volume). Here it is only necessary to describe the construction and nature of the three-dimensional data set for ocean temperatures that groups have the option of using to initialise their ocean models for PlioMIP Experiment 2.

\subsection{The PRISM3D data set of ocean temperatures}

The PRISM3D deep ocean temperature reconstruction (Fig. 2) is presented at a $4^{\circ}$ latitude by $5^{\circ}$ longitude resolution with 33 depth layers, based upon 27 localities, unevenly distributed among the ocean basins. While not optimal for generating a global reconstruction, this represents possibly the largest number of temperature estimates for any deep-water reconstruction from any time interval. Specific steps in the reconstruction methodology are listed in Dowsett et al. (2009) Supplement A (http://www.clim-past. net/5/769/2009/cp-5-769-2009-supplement.pdf). Because the PRISM3D reconstruction is designed for coupled oceanatmosphere general circulation models, it represents a reconstruction of a prescribed day, arbitrarily chosen to be 1 December (this does not imply that climate models must be integrated from this date). The PRISM3D November and December monthly SST reconstructions were averaged to approximate the SST for mid-Pliocene 1 December. A surfacetemperature anomaly was created by subtracting the modern 1 December SST field (Reynolds and Smith, 1995) from the Pliocene 1 December data. The surface temperature anomaly was then added to the $0 \mathrm{~m}$ layer of Levitus and Boyer (1994) (converted to a $4^{\circ} \times 5^{\circ}$ resolution) to create the PRISM3D $0 \mathrm{~m}$ reconstruction. Since no data points fall between $0 \mathrm{~m}$ and $1100 \mathrm{~m}$ in the deep ocean temperature data set, PRISM chose to use a mathematical function that decreases the weight of the surface anomaly with depth down to $1400 \mathrm{~m}$ (see Dowsett et al., 2009). Between $900 \mathrm{~m}$ and $1400 \mathrm{~m}$ that anomaly was further modified based upon data from Southern Ocean sites to accomplish an adjustment or vertical expansion of palaeo Antarctic Intermediate Water (AAIW).

In the Atlantic sector of the Southern Ocean, data suggest warmer palaeo NADW expansion in the region relative to modern day (Dowsett et al., 2009). Warm anomalies for the mid-Pliocene at all sites are in keeping with the hypothesized warmer and stronger flux of palaeo NADW and diminished (colder) palaeo Antarctic Bottom Water production relative to today. In the western Pacific, sites that monitor Pacific Deep Water today show small positive anomalies for the midPliocene. PRISM interprets these data to indicate the overall warmer conditions of the water masses that mixed to form palaeo $\mathrm{PDW}$. In the eastern Pacific, temperature data can be explained by a vertical displacement of AAIW concomitant with overall warming of PDW.

A complete discussion of the rationale and methodology used for the PRISM Deep Ocean Temperature reconstruction can be found in Dowsett et al. (2009).

\section{Data management and planned analyses}

PlioMIP has adopted the established variables list outlined by the second phase of the PMIP (Braconnot et al., 2007a, b). Model outputs will be submitted 


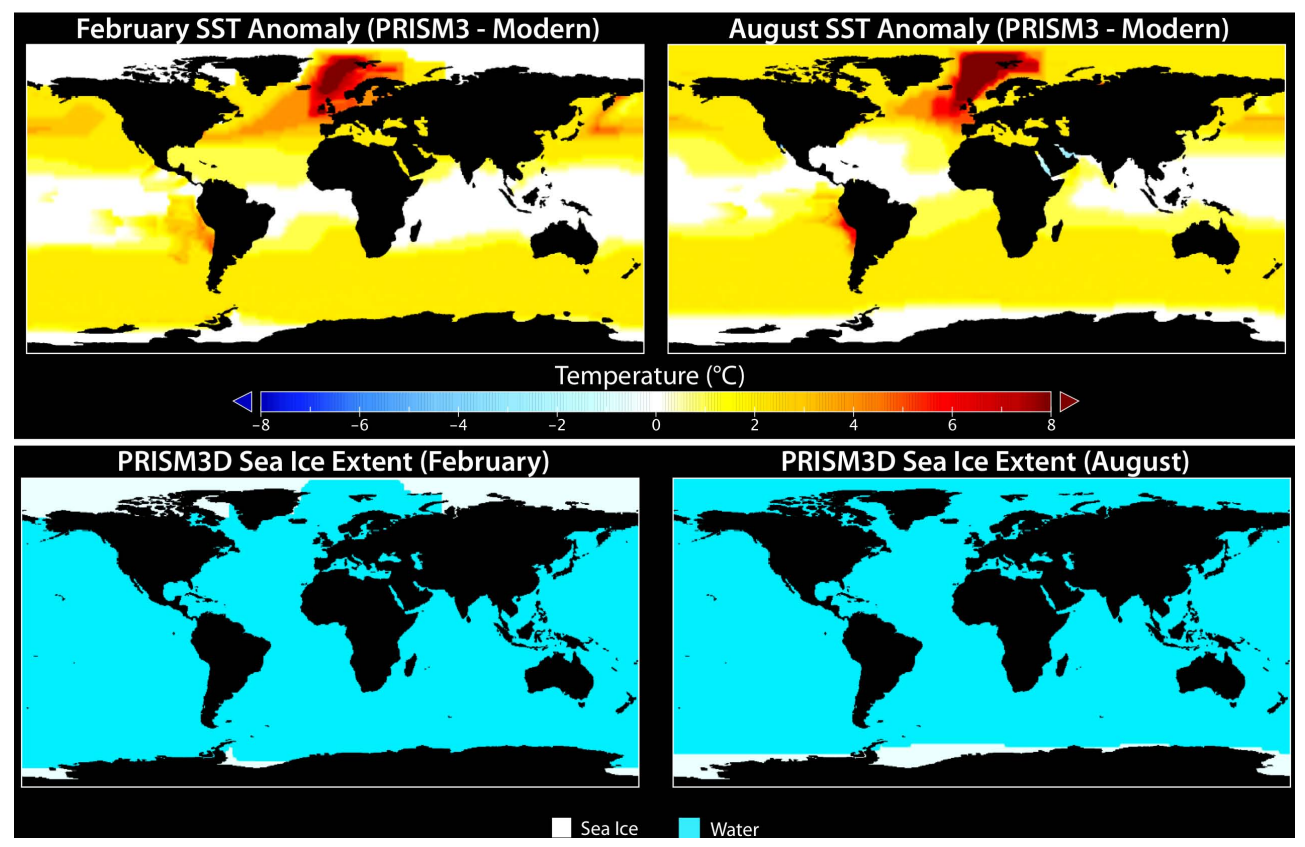

Fig. 1. PRISM3D SST anomaly for February (top left) and August (top right). PRISM3D sea-ice extent for February (bottom left) and August (bottom right).
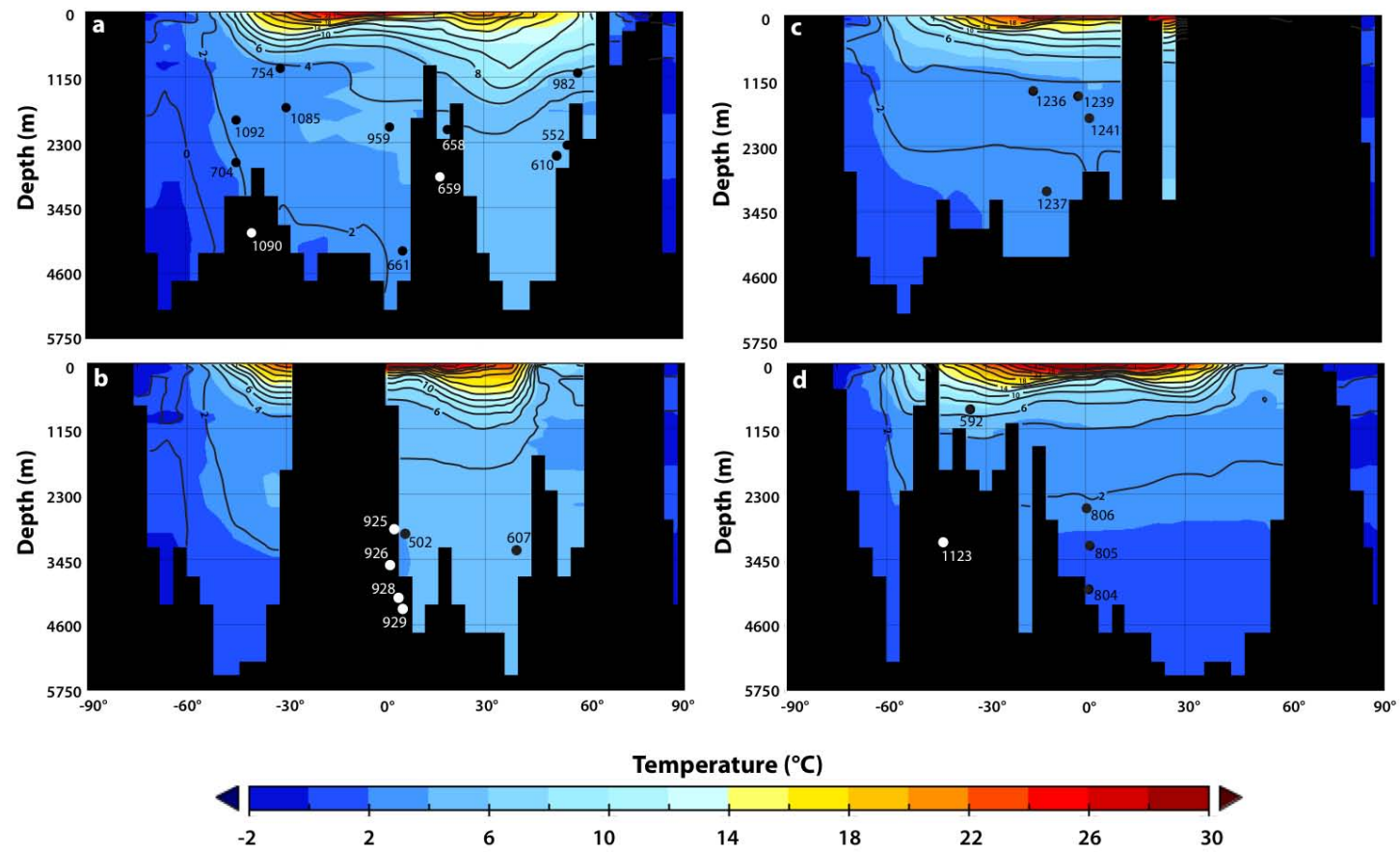

Fig. 2. Longitudinal profiles of ocean temperature from transects at (a) $15^{\circ} \mathrm{W}$, (b) $45^{\circ} \mathrm{W}$, (c) $90^{\circ} \mathrm{W}$ and (d) $165^{\circ} \mathrm{E}$. All temperatures are shown in ${ }^{\circ} \mathrm{C}$. Contour interval is $2^{\circ} \mathrm{C}$. Black contour lines show modern temperature overlaid on coloured regions showing the mid-Pliocene reconstruction. The change in temperature can be surmised by comparing the colour contours to the black overlaid contour lines. For example, in panel (d), Site 806 is slightly cooler than $2{ }^{\circ} \mathrm{C}$ in the modern ocean but was slightly warmer than $2{ }^{\circ} \mathrm{C}$ during the mid-Pliocene (modified from Dowsett et al., 2009). 
and stored within the PMIP2 database. Specifically, for PlioMIP Experiment 1, this refers to PMIP2 recommended outputs for the atmosphere (outlined on the PMIP2 website http://pmip2.lsce.ipsl.fr/> Experimental Design $>$ Variables $>$ Atmosphere). PMIP/PlioMIP requires participants to prepare their data files so that they meet the following constraints (regardless of the way their models produce and store their results).

- The data files have to be in the (now widely used) netCDF binary file format and conform to the CF (Climate and Forecast) metadata convention (outlined on the website http://cf-pcmdi.llnl.gov/).

- There must be only one output variable per file.

- For the data that are a function of longitude and latitude, only regular grids (grids representable as a Cartesian product of longitude and latitude axes) are allowed.

- The file names have to follow the PMIP2 file name convention and be unique.

Participants are encouraged to create the files for submission to the database using the CMOR (Climate Model Output Rewriter) library. This library has been specially developed to help meet the requirements of the Model Intercomparison Projects. Details of the CMOR library are provided on the PMIP2 website (http://pmip2.lsce.ipsl.fr/> Experimental design $>$ Output format $>$ CMOR library). Proposals for model analyses using PlioMIP Experiment 1 data can be made using the established protocols outlined on the PlioMIP website.

\section{Conclusions}

This paper provides a model intercomparison project description for the Pliocene Model Intercomparison Project (PlioMIP) and documents in detail the experimental design. Specifically, this paper describes the experimental design and boundary conditions utilised for Experiment 2 of PlioMIP, following a companion paper for Experiment 1. Experiment 2 will utilise coupled ocean-atmosphere models and will enable the sensitivity of the simulated coupled oceanatmosphere system in a palaeoclimate context to be explored. It also provides the necessary foundation for further sensitivity tests as part of PlioMIP that will explore uncertainties introduced in the climate modelling from specified trace gases and orbital configurations etc.

\section{Supplementary material related to this article is available online at: http://www.geosci-model-dev.net/4/571/2011/ gmd-4-571-2011-supplement.zip.}

Acknowledgements. This work is a product of the US Geological Survey PRISM (Pliocene Research, Interpretation and Synoptic Mapping) Project and the Pliocene Model Intercomparison Project (PlioMIP), which is part of the international Palaeoclimate Modelling Intercomparison Project (PMIP). HD and MR thank the USGS Office of Global Change for their support. AH and DL acknowledge the UK Natural Environment Research Council for funding the UK contribution to PlioMIP (NERC Grant NE/G009112/1). AH acknowledges the Leverhulme Trust for their support through the award of a Philip Leverhulme Prize as well as the European Research Council for the provision of a Starting Grant (ERC StG 278636: Plio-ESS).

Edited by: J. C. Hargreaves

\section{References}

Berggren, W. A., Kent, D. V., Swisher, C. C., and Aubry, M. P.: A revised Cenozoic geochronology and chronostratigraphy, in: Geochronology, time scales and global stratigraphic correlation, edited by: Berggren, W. A., Kent, D. V., Aubry, M. P., and Hardenbol, J., Tulsa, Soc. Sed. Geol., Spec. Pub. 54, 129-212, 1995.

Braconnot, P., Otto-Bliesner, B., Harrison, S., Joussaume, S., Peterchmitt, J.-Y., Abe-Ouchi, A., Crucifix, M., Driesschaert, E., Fichefet, Th., Hewitt, C. D., Kageyama, M., Kitoh, A., Lan, A., Loutre, M.-F., Marti, O., Merkel, U., Ramstein, G., Valdes, P., Weber, S. L., Yu, Y., and Zhao, Y.: Results of PMIP2 coupled simulations of the Mid-Holocene and Last Glacial Maximum Part 1: experiments and large-scale features, Clim. Past, 3, 261277, doi:10.5194/cp-3-261-2007, 2007a.

Braconnot, P., Otto-Bliesner, B., Harrison, S., Joussaume, S., Peterchmitt, J.-Y., Abe-Ouchi, A., Crucifix, M., Driesschaert, E., Fichefet, Th., Hewitt, C. D., Kageyama, M., Kitoh, A., Loutre, M.-F., Marti, O., Merkel, U., Ramstein, G., Valdes, P., Weber, L., Yu, Y., and Zhao, Y.: Results of PMIP2 coupled simulations of the Mid-Holocene and Last Glacial Maximum - Part 2: feedbacks with emphasis on the location of the ITCZ and mid- and high latitudes heat budget, Clim. Past, 3, 279-296, doi:10.5194/cp-3-279-2007, 2007b

Dowsett, H. J.: The PRISM palaeoclimate reconstruction and Pliocene sea-surface temperature, edited by: Williams, M., Haywood, A. M., Gregory, J., and Schmidt, D. N., in: Deeptime perspectives on climate change: Marrying the signal from computer models and biological proxies, Micropalaeontological Soc., Spec. Pub., Geol. Soc. of London, London, UK, 459-480, 2007.

Dowsett, H. J., Barron, J. A., Poore, R. Z., Thompson, R. S., Cronin, T. M., Ishman, S. E., and Willard, D. A.: Middle Pliocene paleoenvironmental reconstruction: PRISM 2, U.S. Geol. Surv., Open File Rep., 99-535, 1999.

Dowsett, H. J., Robinson, M. M., and Foley, K. M.: Pliocene threedimensional global ocean temperature reconstruction, Clim. Past, 5, 769-783, doi:10.5194/cp-5-769-2009, 2009.

Haywood, A. M., Chandler, M. A., Valdes, P. J., Salzmann, U., Lunt, D. J., and Dowsett, H. J.: Comparisons of mid-Pliocene climate predictions produced by the HadAM3 and GCMAM3 General Circulation Models, Global Planet. Change, 66, 208$224,2009$. 
Haywood, A. M., Dowsett, H. J., Otto-Bliesner, B., Chandler, M. A., Dolan, A. M., Hill, D. J., Lunt, D. J., Robinson, M. M., Rosenbloom, N., Salzmann, U., and Sohl, L. E.: Pliocene Model Intercomparison Project (PlioMIP): experimental design and boundary conditions (Experiment 1), Geosci. Model Dev., 3, 227-242, doi:10.5194/gmd-3-227-2010, 2010.

Jones, S. M., White, N., and Maclennan, J.: V-shaped ridges around Iceland: implications for spatial and temporal patterns of mantle convection, Geochem. Geophy. Geosy., 3, 1059, doi:101029/2002GC000361, 2002.

Kürschner, W. M., Van der Burgh, J., Visscher, H., and Dilcher, D. L.: Oak leaves as biosensors of late Neogene and early Pleistocene paleoatmospheric $\mathrm{CO}_{2}$ concentrations, Mar. Micropaleontol., 27, (1/4), 299-312, 1996.

Laskar, J., Robutel, P., Joutel, F., Gastineau, M., Correia, A. C. M., and Levrard, B.: A long term numerical solution for the insolation quantities of the Earth. Astron. Astrophys., 428, 261-285, doi:10.1051/0004-6361:20041335, 2004.

Levitus, S. and Boyer, T. P.: World Ocean Atlas 1994, Volume 2: Oxygen. NOAA Atlas NESDIS 2. U.S. Department of Commerce, NOAA, NESDIS, 1994.
Pagani, M., Liu, Z., LaRiviere, J., and Ravelo, A. C.: High Earth-system climate sensitivity determined from Pliocene carbon dioxide concentrations, Nature Geosci., 3, 27-30, 2010.

Raymo, M. E., Grant, B., Horowitz, M., and Rau, G. H.: Mid-Pliocene warmth: Stronger greenhouse and stronger conveyor, Mar. Micropaleontol., 27, 313-326, doi:10.1016/03778398(95)00048-8, 1996.

Reynolds, R. W. and Smith, T. M.: A high-resolution global sea surface temperature climatology, J. Climate, 8, 1571-1583, 1995.

Robinson, M. M., Valdes, P. J., Haywood, A. M., Dowsett, H. J. Hill, D. J., and Jones, S. M.: Bathymetric controls on Pliocene North Atlantic and Arctic sea surface temperature and deepwater production, Palaeogeogr. Palaeocl., doi:10.1016/j.palaeo.2011.01.004, in press, 2011.

Seki, O, Foster, G. L., Schmidt, D. N., Mackensen, A., Kawamura, K., and Pancost, R. D.: Alkenone and boron-based Pliocene $\mathrm{pCO}_{2}$ records, Earth Planet. Sci. Lett., 292, (1-2), 201-211, 2010.

Shackleton, N. J., Crowhurst, S., Hagelberg, T., Pisias, N. G., and Schneider, D. A.: A new Late Neogene time scale: Application to Leg 138 sites, Proc. ODP Sci. Results, 73-101, 1995. 